\title{
THE INFLUENCE OF ATTACHMENT AND QUALITY OF PARENTING AND PARENTING ENVIRONMENT ON CHILDREN'S CHARACTER IN RURAL AND URBAN AREAS OF BOGOR
}

\author{
Mustika Dewanggi ${ }^{1^{*}}$, Dwi Hastuti ${ }^{2}$, Tin Herawati ${ }^{2}$ \\ ${ }^{1}$ Program Studi IImu Keluarga dan Perkembangan Anak, Sekolah Pascasarjana, Institut Pertanian Bogor, \\ Bogor 16680, Indonesia \\ ${ }^{2}$ Departemen IImu Keluarga dan Konsumen, Fakultas Ekologi Manusia, Institut Pertanian Bogor, \\ Bogor 16680, Indonesia
}

${ }^{*}$ E-mail: mustikadewanggi@gmail.com

\begin{abstract}
This study aimed to analyze the influence of attachment, environmental quality of parenting (HOME), and parental acceptance rejection -as indicator of quality of parenting- on preschool children's character in rural and urban areas of Bogor. The population of the study was intact families with the eldest child aged 3-6 years and lives together with the parents. The sample of this research was selected by simple random sampling $(n=100$, $50 \%$ live in rural area). The result showed that the average score of attachment in rural areas was higher than in urban areas. There was a significant difference of maternal attachment between participants in rural and urban area. The average score of the environmental quality of parenting in rural was higher than in urban area, while the average score of parental acceptance-rejection in rural area was lower than in urban area. Average score of children's character in urban area was higher and significantly different compared to participants in urban area. Regression analysis showed that the child's sex, child's age, mother's age, and attachment were significantly associated with the character of the child.
\end{abstract}

Keywords: attachment, character, environmental quality of parenting, parental acceptance rejection, preschool children

\section{Pengaruh Kelekatan, Kualitas Pengasuhan, dan Kualitas Lingkungan Pengasuhan terhadap Karakter pada Anak Perdesaan dan Perkotaan di Bogor}

\begin{abstract}
Abstrak
Penelitian ini bertujuan untuk menganalisis pengaruh kelekatan ibu dan anak, kualitas lingkungan pengasuhan (HOME), dan pengasuhan penerimaan-penolakan -sebagai indikator kualitas pengasuhan- terhadap karakter anak perdesaan dan perkotaan di Bogor. Populasi penelitian ini adalah keluarga lengkap dengan anak pertama usia 3 hingga 6 tahun dan tinggal bersama orang tuanya. Contoh pada penelitian ini dipilih secara acak (random sampling) yang melibatkan 100 responden (50\% nya berasal dari perdesaan). Hasil penelitian menunjukkan bahwa rata-rata skor kelekatan ibu dengan anak di perdesaan lebih tinggi dibandingkan dengan di perkotaan. Uji beda menunjukkan adanya perbedaan yang signifikan dari kelekatan ibu di perdesaan dengan di perkotaan. Rata-rata skor kualitas lingkungan pengasuhan ibu di perdesaaan lebih tinggi dibandingkan dengan di perkotaan, sedangkan rata-rata skor gaya pengasuhan di perdesaan lebih rendah dibandingkan dengan di perkotaan. Rata-rata skor karakter anak di perkotaan lebih tinggi dibandingkan dengan di perdesaan. Hasil uji beda menunjukkan perbedaan yang signifikan dari karakter anak di perdesaan dengan di perkotaan. Hasil analisis regresi menunjukkan bahwa jenis kelamin anak, usia anak, usia ibu, dan kelekatan berpengaruh signifikan terhadap karakter anak usia prasekolah.
\end{abstract}

Kata kunci: anak usia prasekolah, karakter, kelekatan ibu dan anak, kualitas lingkungan pengasuhan, pengasuhan penerimaan-penolakan

\section{INTRODUCTION}

Alcoholism, free sex, and the decline in the value of respect and honesty in adolescents are various cases that indicate the decline in quality in human resource. It is a critical problem as the quality of human is important for nation building.
Immoral acts committed by juveniles are accumulation of experiences and development throughout life (Wickliffe, 2000).

One of individual development aspects moral identity or character. A person with character a individual who knows about good 
(knowing the good), desire and love goodness (loving the good) and do good (acting the good) (Lickona, 1994). Early childhood is the best time to shape children's development and it will provide long-term impact to the life of children when they grow up (Megawangi, 2009). One of the main things in the character formation is the role of parents through positive parenting (Lickona, 1994).

Positive parenting can shape young people who is less involved in crime, better emotional and social intelligence, and good moral character (Hastuti, 2009; Pasaribu, Hastuti, \& Alfiasari, 2013). Beside parenting, culturally diverse child's environment (related to participation and reflection in social interaction in different situations) are also associated with the care and development of children's character (Wainryb, 2005). However, there are gaps in the knowledge about the differences in the quality of care for children in rural and urban area. In addition rural and urban areas in the border region has a variety of resource limitations to inhibit the function of family, including parenting functions (Maher, Frestedt, \& Grace, 2008; Budianta, 2010).

Based on the previous explanation, families that reside in rural and urban areas, especially in the border areas, are at risks that may hinder the development of the child, including the child's character development. Under these conditions, the study aimed to determine the effect of attachment, environmental quality and parental acceptance rejection of children character in rural and urban areas. The specific objectives of this study: (1) to analyze the differences between attachment, environmental quality and parental acceptance rejection, and the character of children in rural and urban areas, (2) to analyze the relationship between family characteristics with attachment, environmental quality and parental acceptance rejection, and character of the child, (3) to analyze the effect of family characteristics, attachment, environmental quality and parental acceptance rejection on the character.

\section{METHOD}

This is a cross sectional study, which is part of the larger project entitled "Development of Character Values Socialization Method in the Rural Family through the Application of Positive Parenting" that was funded by the Higher Education. The location of the study (selected purposively) was the Village Urug as the representative of rural areas and the Situgede village as the representative of urban areas, both village are located in the periphery of Bogor region and municipality respectively. This research was held from July 2013-September 2013.

The research population was intact families in rural and urban areas which the eldest child was aged 3-6 years and lived in one house, in the two selected areas. Sampling framework in this study selected random sampling. The total population in village Urug, District Sukajaya, Regency of Bogor was 104 respondents, while in Situgede Village, Bogor was 102 respondents. The samples have been taken based on the number of population in the two villages according to the Slovin formula, it took as many as 50 respondents in each place so this study involved 100 respondents.

The type of data consists of primary data and secondary data. The primary data obtained through interviews and observations toward mother and child by using questionnaire, including data of: (1) characteristics of the child (age and sex), (2) parental characteristics (age, length of education, per capita income, and family size), (3) parenting consisted of three aspects, those were: maternal and child attachment by Lamont (2010) with 10 question ítems; parenting style acceptance-rejection (Parental acceptance rejection/PAR) developed by Rohner, Khaleque, \& Cournoyer (2007) as many as 60 items of the question; and the quality of the parenting environment or HOME (Home Observation and Measurement of Environmental Inventory for Early Childhood) by Caldwell and Bradley (1984) with 55 items question. The character of the child was measured using the instrument of Character Strengths self-developed by Peterson \& Seligman (2004) and Lickona (1994) includes 6 (six) dimensions, namely wisdom, courage, humanity, justice, temperance, transcendence and were divided into three parts (knowing, feeling, and acting) with 66 question items.

Data processing for this research used Microsoft Excel and SPSS for Windows. Quality control data using validity and reliability. Likert scale with answer chioces was used for questionnaire of attachment, parenting styles, parenting environmental quality, and character of the child. Then the total score of each questionnaire transformed into the index scores. Analysis in this study has done by using descriptive and inferential analysis consisted of different test t-test, Pearson correlation, and multiple linear regression which was formulated as follows: 


$$
\begin{aligned}
Y= & \beta_{1} X_{1}+\beta_{2} X_{2}+\beta_{3} X_{3}+\beta_{4} X_{4}+\beta_{5} X_{5}+\beta_{6} X_{6}+ \\
& \beta_{7} X_{7}+\beta_{8} X_{8}+\beta_{9} X_{9}+\beta_{10} X_{10}+\beta_{11} X_{11}+\beta_{12} X_{12} \\
& +\beta_{13} X_{13}+\beta_{14} X_{14}+\beta_{15} X_{15}+\beta_{16} X_{16}+\beta_{17} X_{17}+ \\
& \beta_{18} X_{18}+\beta_{19} X_{19}+\beta_{20} X_{20}+\beta_{21} X_{21}+\beta_{22} X_{22}+e
\end{aligned}
$$

Description:

$Y=$ the character of the child

$\beta 1-22=$ regression coefficients

$\mathrm{X} 1, \mathrm{X} 2, \mathrm{X} 3, \mathrm{X} 22=\ldots .$. independent variables

(X1) the child's gender $(0=$ female, $1=$ male $)$

(X2) child's age (years)

(X3) father's age (years)

(X4) mother's age (years)

(X5) mother's education (years)

(X6) mother's employment status $(0=$ not working, $1=$ working)

(X7) number of family members (people)

(X8) family income per capita (rupiah/ month)

(X9) region $(0=$ rural, $1=$ city)

(X10) viscosity (score)

(X11) learning stimulation

(X12) language stimulation (score)

(X13) physical environment (scores)

(X14) warmth and acceptance (score)

(X15) academic stimulation (score)

(X16) modeling (score)

(X17) variation stimulation (score)

(X18) punishment (scores)

(X19) acceptance (score)

(X20) violence (score)

(X21) neglect (score)

(X22) rejection (score)

$\mathrm{e}=$ error

\section{RESULTS}

\section{Characteristics of Children and Families}

Data in Table 1 showed that the average age of children in rural areas was 4,32 years and 4,08 years for children in the urban areas. Family characteristics consisted of father's age, mother's age, length of father's education, length of mother's education, family size, and family income per capita. The average of father's age (28,42 years) and mother's $(23,90$ years) in rural area were younger than the average of father's age $(33,84$ years $)$ and mother's (28,48 years) in urban areas.

The average of formal education length of fathers (4,76 years) and mothers (4,68 years) in rural area were lower than the average of of fathers (9,64 years) and mothers (9,22 years) in urban areas. Number of children of families in rural and urban areas was in the same average (one child) (Table 1). The average site of families in rural areas (3 people) was lower than in urban areas (4 people). Average per capita income in rural families (375.500 Rupiah) was lower than in urban families (380.430 Rupiah).
Table 1 The minimum, maximum, average,

\begin{tabular}{|c|c|c|c|}
\hline \multirow[b]{2}{*}{$\begin{array}{l}\text { Characteristics } \\
\text { variable of } \\
\text { children and } \\
\text { families }\end{array}$} & Rural & Urban & \multirow[b]{2}{*}{$\begin{array}{l}\text { t- test } \\
\text { (sig. 2- } \\
\text { tailed) }\end{array}$} \\
\hline & $\begin{array}{c}\text { Average } \\
\pm \\
\text { Standard } \\
\text { deviation }\end{array}$ & $\begin{array}{c}\text { Average } \\
\pm \\
\text { Standard } \\
\text { deviation }\end{array}$ & \\
\hline $\begin{array}{l}\text { Child's age } \\
\text { (year) }\end{array}$ & $\begin{array}{c}4,32 \pm \\
1,13\end{array}$ & $\begin{array}{c}4,08 \pm \\
1,05\end{array}$ & 0,274 \\
\hline $\begin{array}{l}\text { Father's age } \\
\text { (year) }\end{array}$ & $\begin{array}{c}28,42 \pm \\
37,31\end{array}$ & $\begin{array}{c}33,84 \pm \\
95,69\end{array}$ & $0,000^{*}$ \\
\hline $\begin{array}{l}\text { Mother's age } \\
\text { (year) }\end{array}$ & $\begin{array}{c}23,90 \pm \\
35,87\end{array}$ & $\begin{array}{c}28,48 \pm \\
52,73\end{array}$ & $0,000^{*}$ \\
\hline $\begin{array}{l}\text { Father's } \\
\text { education } \\
\text { length (year) }\end{array}$ & $\begin{array}{l}4,76 \pm \\
23,17\end{array}$ & $\begin{array}{l}9,64 \pm \\
29,88\end{array}$ & $0,000^{*}$ \\
\hline $\begin{array}{l}\text { Mother's } \\
\text { education } \\
\text { length (year) }\end{array}$ & $\begin{array}{l}4,68 \pm \\
19,94\end{array}$ & $\begin{array}{l}9,22 \pm \\
27,72\end{array}$ & $0,000^{*}$ \\
\hline $\begin{array}{l}\text { Number of } \\
\text { family member } \\
\text { (people) }\end{array}$ & $\begin{array}{l}3,52 \pm \\
10,54\end{array}$ & $\begin{array}{c}4,58 \pm \\
16,55\end{array}$ & $0,000^{*}$ \\
\hline $\begin{array}{l}\text { Family income } \\
\text { Per capita } \\
\text { (Rp/month) }\end{array}$ & $\begin{array}{c}375.500 \\
\pm \\
227.670\end{array}$ & $\begin{array}{c}380.430 \\
\pm \\
353.310\end{array}$ & 0,934 \\
\hline
\end{tabular}
and standard deviation of characteristics of children and families in each area

\section{Parenting}

Parenting in this study viewed from three processes, namely maternal and child attachment (which formed an emotional bond between specific individual with the child, binding their role in an eternal closeness), parental acceptance and rejection, as well as the quality of the parenting environment. The results showed that the attachment of mothers and children in rural areas $(61,33)$ was higher compared to the urban areas $(51,75)$.

Different test results showed that there was a significant difference between attachment in rural areas with urban areas $(p<0,01) \quad$ (Table 2). Average of parental acceptance-rejection in rural areas $(76,38)$ was lower than in urban areas $(79,28)$. Different test results discovered that there was no significant difference in maternal acceptance-rejection score between participants in rural and urban areas $(p>0,05)$. Environmental quality of parenting in rural areas $(30,03)$ average was higher than in urban areas $(25,63)$. Different test results showed that there was no significant difference in the environmental quality of maternal parenting score between participans in rural and urban areas $(p>0,05)$ (Table 2). The minimum, maximum, average, and standard deviation of parenting in rural and urban area is depicted in Table 2. 
Table 2 The minimum, maximum, average, and standard deviation of parenting in each area

\begin{tabular}{|c|c|c|c|}
\hline \multirow[b]{2}{*}{ Parenting } & Rural & Urban & \multirow[b]{2}{*}{$\begin{array}{c}\text { Different } \\
\text { T- test } \\
\text { (sig. 2- } \\
\text { tailed) }\end{array}$} \\
\hline & $\begin{array}{c}\text { Average } \\
\pm \\
\text { Standard } \\
\text { deviation }\end{array}$ & $\begin{array}{l}\text { Average } \\
\pm \\
\text { Standard } \\
\text { deviation }\end{array}$ & \\
\hline Attachment & $\begin{array}{c}61,33 \pm \\
9,55\end{array}$ & $\begin{array}{c}51,75 \pm \\
14,84\end{array}$ & $0,000^{*}$ \\
\hline \multicolumn{4}{|c|}{ Parental Acceptance Rejection (PAR) } \\
\hline Acceptance & $\begin{array}{c}85,60 \pm \\
12,41\end{array}$ & $\begin{array}{c}78,60 \pm \\
11,86\end{array}$ & \\
\hline $\begin{array}{l}\text { Aggression/ } \\
\text { violent }\end{array}$ & $\begin{array}{c}30,71 \pm \\
13,10\end{array}$ & $\begin{array}{l}25,0 \pm \\
12,47\end{array}$ & \\
\hline Neglect & $\begin{array}{c}23,77 \pm \\
11,03\end{array}$ & $\begin{array}{c}19,46 \pm \\
9,29\end{array}$ & \\
\hline Rejection & $\begin{array}{c}20,73 \pm \\
12,99\end{array}$ & $\begin{array}{c}16,33 \pm \\
8,99\end{array}$ & \\
\hline Total PAR & $\begin{array}{l}76,38 \pm \\
7,65 \\
\end{array}$ & $\begin{array}{c}79,28 \pm \\
5,19\end{array}$ & 0,505 \\
\hline \multicolumn{4}{|c|}{ Environtmental Quality of Parenting (HOME) } \\
\hline $\begin{array}{l}\text { Learning } \\
\text { stimulation }\end{array}$ & $\begin{array}{c}66,54 \pm \\
16,36\end{array}$ & $\begin{array}{l}51,09 \pm \\
20,19\end{array}$ & \\
\hline $\begin{array}{l}\text { Language } \\
\text { stimulation }\end{array}$ & $\begin{array}{l}6,85 \pm \\
14,49\end{array}$ & $\begin{array}{l}4,0 \pm \\
14,72\end{array}$ & \\
\hline $\begin{array}{l}\text { The physical } \\
\text { environment }\end{array}$ & $\begin{array}{c}32,28 \pm \\
28,25\end{array}$ & $\begin{array}{c}24,85 \pm \\
26,10\end{array}$ & \\
\hline $\begin{array}{l}\text { The warmth } \\
\text { and } \\
\text { acceptance }\end{array}$ & $\begin{array}{c}22,85 \pm \\
34,39\end{array}$ & $\begin{array}{c}19,42 \pm \\
25,45\end{array}$ & \\
\hline $\begin{array}{l}\text { Academic } \\
\text { stimulation }\end{array}$ & $\begin{array}{c}10,80 \pm \\
23,28\end{array}$ & $\begin{array}{c}10,80 \pm \\
16,26\end{array}$ & \\
\hline Modelling & $\begin{array}{c}22,40 \pm \\
20,57\end{array}$ & $\begin{array}{c}22,80 \pm \\
18,52\end{array}$ & \\
\hline $\begin{array}{l}\text { Variations of } \\
\text { stimulation }\end{array}$ & $\begin{array}{c}30,00 \pm \\
20,60\end{array}$ & $\begin{array}{c}34,66 \pm \\
18,04\end{array}$ & \\
\hline Punishment & $\begin{array}{c}12,50 \pm \\
22,16 \\
\end{array}$ & $\begin{array}{l}7,50 \pm \\
20,97 \\
\end{array}$ & \\
\hline Total HOME & $\begin{array}{c}30,03 \pm \\
11,80\end{array}$ & $\begin{array}{c}25,63 \pm \\
9,33\end{array}$ & 0,174 \\
\hline
\end{tabular}

\section{Children's Character}

The character of children in this study is divided into six dimensions consisted of wisdom, courage, humanity, justice, temperance, and transcendence (Peterson \& Seligman, 2004). There were two dimensions of the average child's character that was higher score in rural areas than in urban areas, those were wisdom and knowledge $(77,3)$ as well as the humanity dimension $(30,71)$. There were several character dimension of children in urban areas that were higher than in rural, which were courage $(72,91)$, justice $(73,33)$, temperance $(72,44)$, and the transcendence $(65,77)$. Then, when viewed as a whole, the average of total character children in the rural $(61,81)$ was lower than in urban areas $(72,36)$.

Lickona (1994) explained that the human character is an individual who knows about good (knowing the good), desiring and loving kindness (loving the good) and do good (acting the good). Those three parts of the children character showed that the average character of knowing $(62,59)$, feeling $(46,18)$, and acting $(76,68)$ of children in rural areas were lower than children's character in urban areas. Different test results showed that there were significant difference between the character of children in rural areas with urban areas $(p<0,05)$. Mean, standard deviation, and different test coefficient of children's character in each area is presented in Table 3.

\section{Variables Associated with Children's Character}

Correlation test results showed a positive and significant correlation between age, father's age, and mother's age with child's character. There was a significant negative correlation between length of education of father and mother with attachment. It explained the longer the father and mother's education, the lower the mother with child attachment will be. Correlation test results discovered a positive and significant correlation between the length of mothers education with parental acceptance. It explained that the longer mother's education, the better parental acceptance will be. There was also a significant negative correlation between length of father's and mother's education with environmental quality of parenting (Table 4).

Table 3 Mean, standard deviation, and different t-test coefficient of children's character in each area

\begin{tabular}{lcc}
\hline \multirow{2}{*}{$\begin{array}{l}\text { Children's } \\
\text { Character }\end{array}$} & \multicolumn{2}{c}{ Rean \pm Standard deviation } \\
\cline { 2 - 3 } $\begin{array}{l}\text { Wisdom and } \\
\text { knowledge }\end{array}$ & $77,33 \pm 21,88$ & Urban \\
Courage & $65,25 \pm 27,86 \pm 26,08$ \\
Humanity & $30,71 \pm 13,10$ & $72,91 \pm 25,02 \pm 10$ \\
Justice & $55,00 \pm 34,30$ & $73,33 \pm 29,24$ \\
Temperance & $55,44 \pm 35,44$ & $72,44 \pm 30,26$ \\
Transcendence & $53,66 \pm 32,23$ & $65,77 \pm 28,31$ \\
Total & $61,81 \pm 27,91$ & $72,36 \pm 25,89$ \\
Knowing & $62,59 \pm 36,84$ & $76,27 \pm 32,33$ \\
Feeling & $46,18 \pm 33,44$ & $57,31 \pm 32,15$ \\
Acting & $76,68 \pm 21,21$ & $83,50 \pm 19,51$ \\
\hline Different T-test & \multicolumn{2}{c}{$0,053^{*}$} \\
(sig, 2-tailed) & \multicolumn{3}{c}{ Note: } \\
**Significant at $p<0,01,{ }^{*}$ Significant at $p<0,05$
\end{tabular}


Table 4 Correlation coefficient between the study variables with the character

\begin{tabular}{lrrrr}
\hline \multirow{2}{*}{ Variables } & \multicolumn{3}{c}{ Coefficients } & Total of children's \\
\cline { 2 - 5 } & Attachment & Parenting style & Parenting environment & character \\
\hline Child's age (year) & $-0,062$ & $-0,097$ & $-0,035$ & 0,474 \\
Father's age (year) & $-0,094$ & 0,154 & $-0,030$ & 0,212 \\
Mother's age (year) & $-0,148$ & 0,037 & $-0,045$ & $0,218^{\star}$ \\
Mother's education length (year) & $-0,200^{\star}$ & $0,279^{\star *}$ & $-0,384^{\star *}$ & 0,110 \\
Number of family member (people) & $-0,123$ & $-0,041$ & $-0,112$ & $-0,047$ \\
Family income per capita (Rp) & $-0,160$ & 0,010 & $-0,080$ & $-0,145$ \\
\hline
\end{tabular}

Note: ${ }^{* *}$ Significant at $p \leq 0,01,{ }^{*}$ Significant at $p \leq 0,05$

\section{Results of Regression Analysis}

Inclusion of variables into the regression model to analyze factors that is influenced by the score of character of preschool children was resulting an Adjusted $R$ Square of 0,309. The results of multiple linear regression indicated that child's sex, child's age, mother's age, and attachment significantly effected on the character of the child (Table 5).

Table 5 Multiple linear regression analysis of the variables that affect the total character of children

\begin{tabular}{|c|c|c|}
\hline Variables & $\mathrm{B}$ & Sig \\
\hline Child's sex (Girls=0, boys $=1$ ) & $-16,874$ & $0,002^{* *}$ \\
\hline Child's age (year) & 15,171 & $0,000^{* *}$ \\
\hline Father's age (year) & $-0,394$ & 0,331 \\
\hline Mother's age (tyear) & 1,166 & $0,071^{*}$ \\
\hline Mother education (year) & 1,476 & 0,201 \\
\hline $\begin{array}{l}\text { Working mother status } \\
(\text { Not working }=0, \text { Working }=1)\end{array}$ & $-7,381$ & 0,330 \\
\hline $\begin{array}{l}\text { Number of family member } \\
\text { (people) }\end{array}$ & $-1,454$ & 0,446 \\
\hline $\begin{array}{l}\text { Family income per capita } \\
\text { (Rp) }\end{array}$ & $-2,947 \mathrm{E}-6$ & 0,742 \\
\hline Region (Rural=0, Urban=1) & 7,380 & 0,387 \\
\hline Attachment & 0,386 & $0,089^{*}$ \\
\hline HOME & & \\
\hline Learning stimulation & 0,105 & 0,520 \\
\hline Language Stimulation & $-0,144$ & 0,406 \\
\hline The physical environment & 0,095 & 0,315 \\
\hline The warmth and acceptance & $-0,019$ & 0,860 \\
\hline Academic stimulation & 0,134 & 0,319 \\
\hline Modeling & $-0,087$ & 0,618 \\
\hline Variations stimulation & 0,194 & 0,209 \\
\hline Punishment & 0,024 & 0,841 \\
\hline PAR & & \\
\hline Acceptance & 0,059 & 0,807 \\
\hline Aggression/Violent & $-0,018$ & 0,945 \\
\hline Neglect & $-0,319$ & 0,268 \\
\hline Rejection & 0,265 & 0,365 \\
\hline F Test (p) & \multicolumn{2}{|c|}{$3,013(0,000)$} \\
\hline Adjusted R Square (df/n) & \multicolumn{2}{|c|}{$0,309(22 / 100)$} \\
\hline
\end{tabular}

\section{DISCUSSION}

The development of a person, including the moral development, starting from conception to adulthood. Researchers from various countries agreed that experience and the optimization effort on the development of children through parenting during preschool time is the best time to shape children's development and it will provide long-term impact to the lives of children, that may have implications to the progress and long-term investments for the benefit of any country (Lickona, 1994). A child's character development is closely linked to nuclear family (father, mother, and siblings) (Arthur, Power, \& Lin, 2012; Hastuti, 2009), family socioeconomic status (Karina, Hastuti, \& Alfiasari, 2013), and the child's culture (Wainryb, 2005)

The average of maternal attachment in rural areas was higher than in urban, different test also showed significant difference between maternal attachment in rural areas with urban areas. It might be caused by secure attachment in children in rural areas was built better, so that children were able to get close to people, cheerful, and loves playing with peers, children were also search for mother immediately when child is frightened or crying, because mother was quick to respond and within reach of children. Mother was always there in the village, close to child and had quickly respond to the child's condition since rural areas were rocky and hilly, so that mother did not let their child away from the mother's side. Although always be near, mother still gave the child freedom to play with friends in the home environment. The situation in the village which had a close relationship within society, also supported the ease of a child to be able to be close and feel safe with other people in addition to mother. This was consistent with results of previous studies, which revealed that rural communities have high levels of maternal and child attachment is quite good, as well as the closeness of kinship among members of society steeper (Permatasari \& Hastuti, 2011). 
The average of maternal acceptance was higher in urban than in rural areas, whereas average of abuse, neglect, and maternal rejection were higher in rural areas than in urban areas. Difference test showed none of significant difference between mother's parental acceptance in rural area with urban. This result was different with the results of previous research conducted by Wahini \& Ismawati (2005), which revealed that urban mothers have higher levels of violence and neglect than in rural areas. This difference is presumably because in rural areas, had become habitual that mothers interact with children through harsh words, blame, low expression of affection through speech, rarely expressing praise, comparing their children with other children, snapped, neglect the question from the child, and assumed that child was troublesome, and complained about the situation of children in front of people. Mother's knowledge of previous parenting experience, low levels of education, and community environments that implement same patterns of interaction, are the causes that will make the difference thing occured.

This study discovered that the average of child's character was higher in urban areas than in rural areas. That is because children in urban areas have a good understanding of the behavior, like doing good and doing acts of kindness. Children in urban areas have a willingness to learn better (wisdom and knowledge), tidy up after finished playing and did not take friends's goods (courage), lend the goods on friends (humanity), loving the younger brother (justice), able to forgive friend (temperance), and loving animals and plants as well as do worshipping practice with parents (transcendence).

Correlation test results showed a positive and significant relationship between age, paternal age, and maternal age with child's character. It explained that the older the child's age, father's age, mother's age, the higher character of the child will be. Moral development of a person related to individual factors such as age (Pranoto \& Kurniawati, 2011). The higher age indicates maturity in the growth and development of the various aspects that can improve moral development. Longer mother's education was significant and positively associated with parenting style, but negatively associated with attachment parenting and environmental quality in signficant way. According to Carneiro, Meghir, \& Parey (2007) mother's education related to how mothers caring for children and the results will not always be the same, it can be caused by parenting experienced by mothers in the past.

The results of multiple linear regression showed that the variables of child's sex, the child's age, maternal age, and attachment effected on the character of preschoolers. According to Hastuti and Alfiasari (2008), sex of the child and the child's increasing age are significantly effected on the character development of children. The older age of children were related to moral and character development of children (Lickona, 1994). The older the mother's age is expected to have the better knowledge and moral development of character, so it can be associated with the child development. Mothers attachment with children also effected on children character. Results of a longitudinal study showed that a secure attachment between mother and child, from an early age will give an impact on children's development when reaching adulthood (Waters et al., 2000). The results of this study also supported the importance of maternal and child attachment as the main foundation (besides interaction and stimulation) for the development of better child character at early age.

Based on the sleeper effect theory, it is stated that the effect of a treatment in childhood will only appear when the child reaches adulthood. These results indicated that, attachment was the only aspect of three aspects in parenting which influenced the nature of children. This is presumably because the results of the overall parenting of these aspects will be visibly affected child's character in the future, after children grew up. According to compiled research by The Centre for Spatial Economics in Canada (2009), it stated that the output of the sleeper effect on children can be negative or positive. It suggested that positive behavior and social development will be enhanced in the future if there were intervention of positive parenting toward children. This research also supported the importance of mother-child attachment as a main foundation (besides interaction and stimulation) to build a better character on preschooler children.

\section{CONCLUSION AND RECOMMENDATIONS}

Results of this study discoverd a significant difference of maternal attachment in rural and urban areas. Difference test results also showed a significant difference of preschool children character in the rural and urban areas. Regression analysis showed that the child's sex, the child's age, maternal age, and attachment significantly influenced on the 
character of preschoolers. The study also showed that the character of children in rural areas was lower than in urban areas.

Therefore, it is necessary to do the socialization to build children character in rural areas. The results also revealed the low acceptance of mothers in rural areas, thus it required the assistance of positive parenting for mothers in rural areas. The results of this study supported the importance of maternal and child attachment as the main foundation (besides interaction and stimulation) for the development of better child character in early age. The results of this study showed none of influence from environmental quality of parenting and parenting style acceptance-rejection on the child character, thus required a longitudinal study to see the impact of parenting on character development when the children reach adolescence.

\section{ACKNOWLEDGEMENT}

Thanks to the research team of entitled "Development of Character Values Socialization Method in the Rural Family through the Application of Positive Parenting", who are Alfiasari, S.P., M.Si., Dr. Ir. Dwi Hastuti, M.Sc., Ir. Moh. Djemdjem Djamaludin, M.Sc., and the enumerators.

\section{REFERENCES}

Arthur, J., Powell, S., \& Lin H. C. (2012). Foundation of character. Eroupean Early Childhood Education Reasearch Journal. doi:10.1080/1350293x.2012.707413.

Budianta, A. (2010). Pengembangan wilayah perbatasan sebagai upaya pemerataan pembangunan wilayah di Indonesia. Jurnal Smartek, 8(1), 72-82.

Carneiro, P., Meghir, C., \& Parey, M. (2007). Maternal education, home environtments and the development of children and adolescents. Iza Discussion Paper No. 3072. Retrieved from http://ftp.iza.org/ dp3072.pdf. [downloaded Oct $9^{\text {th }}$ 2013].

Hastuti, D., \& Alfiasari. (2008). Stimulasi psikososial dan pengaruhnya pada karakter anak yang bersekolah dan tidak bersekolah di taman bermain semai benih bangsa, Kabupaten Aceh Utara, Provinsi NAD, Jur. IIm. Kel. \& Kons., 1(2), 34-45.

Hastuti, D. (2009). Stimulasi psikososial pada anak kelompok bermain dan pengaruh-nya pada perkembangan motorik, kognitif, sosial emosi, dan moral/karakter anak. Jur. IIm. Kel. \& Kons., 2(1), 41-56.

Karina, Hastuti, D., \& Alfiasari. (2013). Perilaku bullying dan karakter remaja serta kaitannya dengan karakteristik keluarga dan peer group. Jur. IIm. Kel. \& Kons., 6(1), 20-29.

Lamont, M. (2010). Mother-child attachment and preschool behavior problems in children with developmental delays (dissertation). Utah State University, Amerika.

Lickona, T. (1994). Raising good children. Amerika, US: Bantam Books.

Maher, E.J., Frestedt, B., \& Grace, C. (2008). Differences in child care quality in rural and non-rural areas. Journal of Research In Rural Education, 23(4).

Megawangi, R. (2009). Pendidikan karakter solusi yang tepat untuk membangun bangsa. Bogor, ID: Indonesia Heritage Foundation.

Pasaribu, R. M., Hastuti, D., \& Alfiasari. (2013). Gaya pengasuhan permisif dan rendahnya sosialisasi nilai dalam keluarga beresiko terhadap penurunan karakter remaja. Jur. IIm. Kel. \& Kons., 6(3). 163-171.

Permatasari, C. L., \& Hastuti, D. (2013). Nilai budaya, pengasuhan penerimaanpenolakan, dan perkembangan sosial anak usia 3-5 tahun pada keluarga Kampung Adat urug, Bogor. Jur. IIm. Kel. \& Kons., 6(2), 91-99.

Peterson, C., \& Seligman, M. E. P. (2004). Character strengths and virtues a handbook and classification. New York, US: Oxford Univercity Press.

Pranoto, S. \& Kurniawati, Y. (2011). Kecerdasan Moral Anak Usia Prasekolah. Jurnal Fakultas IImu Pendidikan Universitas Negeri Semarang. Retrieved from http://unes.ac.id.962-1731-1-pb. [downloaded Oct $9^{\text {th }}$ 2013].

Rohner, R. P., Khaleque, A., \& Cournoyer, D. E. (2007). Introduction to parental acceptance-rejection theory, methods, evidence, and implications. University of Connecticut. Retrieved from http:// www.cspar.uconn.edu. [downloaded May $5^{\text {th }}$ 2013].

The Centre for Spatial Economics for Child Care Human Resources Sector Council. (2009). Understanding and addressing 
workforce shortages in early childhood education and care (ECEC) Project. Retrieved from http://ccsc-cssge.ca. [downloaded Oct $9^{\text {th }}$ 2013].

Wahini, M. \& Ismawati, R. (2005). Pengaruh pola asuh penerimaan-penolakan dan karakteristik anak terhadap perilaku anak diperkotaan dan perdesaan. Lentera, Jurnal Studi Perempuan, 1(2).
Wainryb, C. (2005). Moral development in culture: Diversity, tolerance, and justice. Utah, US: University of Utah.

Waters, E., Metrrick, S., Treboux, D., Crowell, J., \& Albersheim, L. (2000). Attachment security in infancy and early aduldthood: A twenty-year longitudinal study. Child Development, 71(3), 684-689.

Wickliffe, J. A. (2000). Why juveniles commit crimes. Retrieved from: http//:yale.edu/. [downloaded May $5^{\text {th }}$ 2013]. 